\title{
Effect of Application of Humic Acid and Vermiwash on the Growth, Quality and Yield of Plants: A Review
}

\author{
Jatin Hudda $^{1^{*}}$, Ankush Godara ${ }^{2}$ and Sarvjeet Kukreja ${ }^{1}$ \\ ${ }^{1}$ Department of Agronomy, ${ }^{2}$ Department of Horticulture, School of Agriculture, Lovely \\ Professional University, Punjab, India \\ *Corresponding author
}

\section{A B S T R A C T}

\begin{tabular}{l} 
Ke y w o r d s \\
Humic acid, \\
Vermiwash, Bio \\
stimulants, \\
Sustainability \\
\hline Article Info \\
$\begin{array}{l}\text { Accepted: } \\
10 \text { October } 2020 \\
\text { Available Online: } \\
10 \text { November } 2020\end{array}$ \\
\hline
\end{tabular}

\section{Introduction}

Bio stimulants are synthetic or natural substances which can be applied to soil, plants and seeds that cause change to structural or vital physiological processes to enhance plant growth by improving resistance to abiotic stresses and enhance seed or grain yield as well as quality of seeds. Bio stimulants such as humic acid and vermiwash have proven to be beneficial organic amendments to be used in the current scenario of increasing trend of organic farming. It has reduced the dependency on inorganic fertilisers in order to achieve sustainability without compromising the quality and quantity. Humic acid is a natural resource which can be used as an alternative for inorganic fertilisers. Humic acid is a naturally existing polymeric organic compound which is converted due to decay of organic matter and initiated in humus, peat as well as lignite (Sharif et al., 2002). Humic acid consist a combination of organic acids which are aromatic in nature and contain various heterogeneous functional groups that have impervious interaction with different metallic ions such as $\mathrm{Mg}, \mathrm{Zn}, \mathrm{Ca}$ and $\mathrm{Cu}$ (Piccolo 2012). Humic acid can be applied in both ways i.e. soil and foliar application. The soil 
amendment of humic acid ensures soft, pulverized and well aerated soil with nutrient supplements. On the other hand, the foliar spray of humic acid ensures better nutrient uptake, improved permeability and photosynthetic rate. Another such bio stimulant is vermiwash which is mostly used in the form of foliar application. It contains $\mathrm{N}$ $0.29 \%, \mathrm{P} 0.042 \%, \mathrm{~K} 0.143 \%$, Ca $0.186 \%$, $\mathrm{Mg} 0.11 \%$, S $0.058 \%$, Fe 0.466 ppm, Mn $0.406 \mathrm{ppm}, \mathrm{Zn} 0.11 \mathrm{ppm}, \mathrm{Cu} 0.18 \mathrm{ppm}$, (Anonymous, 2007). It is a transparent pale yellow to brown bio fertilizer and a mixture of excretory product and mucous secretion of earth worm (Lampito mautriti and Esenia foetida) and organic micronutrients of soil, which may be promoted as a potent bio fertilizer for better growth and yield (Shweta et al., 2005). Vermicompost wash is having approximately $1300 \mathrm{ppm}$ humic acid, 116 ppm dissolved oxygen, $50 \mathrm{ppm}$ inorganic phosphate, $168 \mathrm{ppm}$ potassium and $121 \mathrm{ppm}$ sodium (Haripriya and Pookodi, 2005). Due to these diverse constituents vermiwash is mostly suited for every plant for better growth and yield. The main aim of this review is to determine the effects of these bio stimulants individually and with combination with other applications on various crops as researched by various researchers.

\section{Effect on physiological parameters}

Physiological parameters such as leaf nutrient, total chlorophyll content, photosynthetic rate, stomatal conductance, transpiration rate determine the inner wellbeing of the plant and proper functioning of the physiological processes of the plant. A comparative study conducted to check the impact of foliar and soil applied humic acid on quality and yield of pepper evaluated the total chlorophyll content and suggested that the maximum value was achieved at soil application of 20ml/litre and 22\% HA followed by foliar based application at same rate (Karakrut et al., 2009). The effect of application of humic acid showed on the pepper fruit as increase in chlorophyll content lead to increase in the green colour. The change in total chlorophyll is caused by the fluctuation in chlorophyll b concentration as no remarkable change was observed in chlorophyll a content under the influence of humic acid (Karakurt et al., 2009).

In another research on soil based application of humic acid and foliar spray vermicompost leachate was used for improving the productivity and quality of mango in North Sanai. It was observed that humic acid $(40 \mathrm{ml} /$ tree) and vermicomposting leachate (15\%) gave the highest total chlorophyll content and leaf mineral nutrition $(\mathrm{N}, \mathrm{P}, \mathrm{K} \%)$ and thus this dose is recommended (Sheren A. Abd El-Hamied, 2018).

Humic acid (8\%) when applied as soil treatment in drip lines on kinnow mandarin at different stages in different doses showed that maximum photosynthetic rate $(97 \%)$ when applied in triplicate dose of $13.3 \mathrm{ml} / \mathrm{plant}$, maximum stomatal conductance $(61 \%)$ and transpiration rate $(57.23 \%)$ when applied in triplicate dose of $26.6 \mathrm{ml} / \mathrm{plant}$, and highest total chlorophyll content (53\%) when applied in triplicate dose of $20 \mathrm{ml} /$ plant were observed (Abbas et al., 2012).

In another study to check the accumulative effect of humic acid and multi nutrient fertiliser it was observed that treatment containing $80 \mathrm{ml}$ of $10 \%$ humic acid and multi nutrient fertiliser when applied in three split doses showed maximum leaf nutrient content (N-24.1\%, P-31.8\%, K-60.1\%), highest total chlorophyll content (26.9\%), highest photosynthetic rate $(46 \%)$, highest stomatal conductance (44.2\%), and highest transpiration rate $(32.3 \%)$ (Hameed et al., 2018). 
Total chlorophyll content and leaf nutrients (NPK) were estimated to be highest in case of foliar application of vermicompost wash (400ppm) to check the effectively in vermicompost wash treated groundnut (Hiradeve et al., 2011).

Further in another experiment, total chlorophyll content and nitrogen content in soybean leaves were found maximum in treatment containing $200 \mathrm{ppm}$ vermiwash in a comparative study of vermiwash and cow dung foliar sprays on biochemical and yield parameters of soybean (Lende et al., 2007). These various studies showed the significant positive effects of humic acid and vermiwash on different crops in context to improvement of physiological parameters.

\section{Effect on nutrient uptake}

The uptake of nutrients is essential for the utilisation of nutrients for growth of the plant and therefore there is a need to study the variation in nutrient uptake when bio stimulants such as humic acid are applied with the nutrients. One such study focused on the behaviour of nutrient uptake in maize under calcareous soils and studied the uptake of various nutrient viz. Nitrogen, Phosphorus, Potassium, Calcium, Magnesium, Iron, Copper, Zinc, Manganese, Sodium and observed that highest copper and sodium uptake was at $0.1 \%$ concentration of humic acid, while for other nutrients the uptake was highest at $0.2 \%$ concentration of humic acid except manganese which had negative impact of humic acid (Celik et al., 2010).

In another study carried on Gerbera, Nutrient uptake was studied at varied concentration of humic acid applied along with nutrient solutions and results revealed that nitrogen uptake can increase by $40 \%, \mathrm{P}$ content by $32 \%$ at $1000 \mathrm{mg} /$ litre humic acid, and $\mathrm{Mg}, \mathrm{Ca}$, $\mathrm{Fe}, \mathrm{Zn}$ content by $157 \%, 585 \%, 49 \%, 10 \%$, respectively, at $500 \mathrm{mg} /$ litre concentration of humic acid (Nikbakht et al., 2008).

\section{Effect on vegetative parameters}

Vegetative parameters such as plant height, leaf area, stem girth, number of leaves per branch etc. decide the growth of the plant which ultimately has a direct effect on the yield and quality of the produce. In a research conducted to check the effects of humic acid through vermiwash and NAA on various parameters of chick pea, it was observed that $50 \mathrm{ppm}$ NAA $+400 \mathrm{ppm}$ humic acid through vermiwash showed maximum leaf area per plant at 45, 65, 85 days (Kapase et al., 2014). The study showed the concentrations at which the vermiwash combined with NAA resulted in maximum leaf area per plant. In another study on soil based application of humic acid and foliar spray of vermicompost leachate for improving the productivity and quality of mango, it was evaluated that humic acid (40 $\mathrm{ml} /$ tree) and vermicompost leachate $(15 \%)$ gave the highest leaf area (Sheren A. Abd ElHamied, 2018). Evaluation of leaf area has significant importance as more leaves will directly account for the increased photosynthetic rate of the plant.

A study was conducted to check the accumulative effect of humic acid applied to the soil with irrigation with multi nutrient fertiliser sprayed at kinnow plant in different concentrations and intervals. It suggested that vegetative attributes like plant height, stem girth, leaves per branch and canopy volume increased with the increased concentration and found the increase of plant height (32.2\%), stem girth (77.2\%), canopy volume $(15 \%)$ was maximum at $80 \mathrm{ml}$ of $10 \%$ humic acid and multi nutrient fertiliser when applied in three split doses (Hameed et al., 2018). In the above study the effect of humic acid was supplemented with the application of the multi nutrient fertilizer and less effective 
individually, thus suggesting the role of humic acid as a synergist and stimulant. Another such example of cumulative effect of humic acid with other supplements is based on the research conducted in strawberry to study the effect of compost, amino acids and humic acids on yield and growth which suggested that plant length of strawberry was maximum $(12.53 \mathrm{~cm})$ at treatment containing $1 / 2$ dose of mineral fertiliser (control) $+1 / 2$ compost (2ton/fed) + humic acid spray (1g/litre) + amino acid foliar spray ( $2 \mathrm{ml} /$ litre) and number of leaves varied insignificantly (Shehta et al., 2011).

\section{Effect on yield and yield contributing parameters}

Yield is the end requirement from any crop and yield is determined in terms of various parameters like for fruits it is number of fruits / tree, and for grains or pulses it is determined in terms of number of pods / plant, 100 seed weight and seed yield / ha, and for some crops it is in terms of dry matter. The yield component is important to consider as it is the component which finally decides the profitability of cultivation of a crop. Maximum number of pods /plant, 100 seed weight and seed yield/ha were observed in treatment of 50ppm NAA+400ppm humic acid through vermiwash in a study on the effect of foliar spray of vermiwash and NAA on chickpea (Kapase et al., 2014). Another research carried on forage turnip for the study of effect of humic acid applied at different time in different concentration on dry matter yield suggested that maximum root and leaf dry matter yields were obtained at $1200 \mathrm{ml} / \mathrm{ha}$ humic acid concentration applied after 1 month of sowing onto the leaves (Albayrak et al., 2005). In another study on soil based application of humic acid and foliar spray of vermicompost leachate for improving the productivity and quality of mango, it was evaluated that humic acid $(40 \mathrm{ml} /$ tree) and vermicompost leachate (15\%) gave the highest fruit set, fruit retention and overall yield of mango (Sheren A. Abd El-Hamied, 2018).In other study carried on kinnow mandarin to know the effects of humic acid at different stages with different doses, results revealed that application of humic acid in three split doses of $26.6 \mathrm{ml} /$ tree resulted in highest number of fruits/tree and reduced the fruit drop percentage by 19\% (Abbas et al., 2013). This finding suggests that application in split doses seems to be more beneficial rather than single dose. Another similar study conducted to check the accumulative effect of humic acid applied to the soil with irrigation in addition with multi nutrient fertiliser sprayed at kinnow plant with different concentrations and intervals suggested that on application of $80 \mathrm{ml}$ of $10 \%$ humic acid and multi nutrient fertiliser when applied in three split doses viz. Feb, March and August resulted in $38.7 \%$ increase in fruits/plant, $22.2 \%$ increase in fruit set/branch and $5.2 \%$ reduction in fruit drop (Hameed et al., 2018).

Vermiwash spray when applied at the rate of $400 \mathrm{ppm}$ in groundnut proved to increase shelling percentage and increase kernel recovery from $85.33 \%$ in control to $95.33 \%$ (Hiradeve et al., 2011). Similar results were reported in soybean where 200ppm vermiwash spray was found to result in increase in dry pod weight/plant and yield/ha (Lende et al., 2007). In another study with tomato plants were subjected to soil application and foliar spray of 10 and $20 \mathrm{ml} /$ litre $23 \%$ humic acid. It was observed that foliar sprayed humic acid @ 20ml/litre gave the highest yield in both the seasons (Ertan Yildirim, 2007).

\section{Effect on biochemical parameters}

Biochemical parameters like total soluble salts, titratable acidity, total sugars, anthocyanin content, protein content, oil 
content etc. determine the quality of the produce. In case of fruits, the biochemical parameters are of the utmost importance as they determine the inner quality of fruits. Humic acid and vermiwash applications have showed significant positive changes in these attributes. The TSS and reducing sugars in pepper were highest in soil applied humic acid@20ml/litre concentration in a comparative research of soil and foliar application of humic acid in case of pepper (Karakurt et al., 2009). Humic acid (8\%) when applied as soil treatment in drip lines on kinnow mandarin at different stages in different doses showed that plants treated with $20 \mathrm{ml} /$ plant humic acid in three stages reported maximum increase in TSS(17.84\%) and maximum decline in acidity (21.91\%), while ascorbic acid increased $(22.96 \%)$ by $13.3 \mathrm{ml} / \mathrm{plant} \mathrm{HA}$ and total sugar increased by $21.34 \%$ by $26.6 \mathrm{ml} / \mathrm{plant}$ humic acid in three split doses (Abbas et al., 2012). This showed that a minor variation in the dosage of humic acid can have positive or negative effects on various biochemical parameters.

In another study cumulative effect of humic acid applied to the soil with irrigation in addition to multi nutrient fertiliser sprayed at kinnow plant in different concentrations and intervals suggested that $80 \mathrm{ml}$ of $10 \%$ humic acid and multi nutrient fertiliser when applied in three split doses resulted in $41 \%$ decrease in total titratable acidity as compared to control, $27.6 \%$ increase in vitamin - C content, $20.8 \%$ increase in TSS and $20.3 \%$ increase in total sugars (Hameed et al., 2018). This suggested major improvement in quality of fruits when application of nutrients is supplemented with humic acid. The oil content in groundnut increased from $45.05 \%$ in control to $48.80 \%$ in $400 \mathrm{ppm}$ vermiwash foliar spray (Hiravede et al., 2011). Similarly, protein and oil content in soybean increased significantly by the application of 200ppm vermiwash foliar spray (Lende et al., 2007).
Thus, the case studies suggested that the humic acid and vermiwash supplementation play an important role in improving the quality of the produce by influencing the biochemical factors.

In conclusion it is clear from the literature cited that humic acid and vermiwash play positive role in enhancing the growth and yield of different crops by influencing various biochemical and physiological attributes either alone or in synergism. The difference between the effect of soil and foliar application is minimal and mostly foliar application gives the best results. The use of these bio stimulants is limited to some crops and need to be widely adapted to other crops mostly in fruits to increase productivity and quality.

\section{References}

Abbas T., Saeed Ahmad, Muhammad Ashraf, Muhammad Adnan Shahid, Muhammad Yasin, Rashad MukhtarBalal, Muhammad Aslam Pervez and Sumaira Abbas, 2012. Effect of humic and application at different growth stages of kinnow mandarin (Citrus reticulatablanco) on the basis of physio-biochemical and reproductive responses. Academia Journal of Biotechnology 1(1): 014-020, January 2013. ISSN: 2315-7747 @2013 Academia Publishing.

Abdel-Mawgoud AMR, El-Greadly NHM, Helmy YI, Singer SM (2007). Responses of tomato plants to different rates of humic based fertilizer and NPK fertilization. J. Appl. Sci. Res. 3:169174.

Adani, F., Genevi, P., Zaccheo, P. and Zocchi, G. 1998. The effect of commercial humic acid on tomato plant growth and mineral nutrition. Journal of Plant Nutrition, 21: 561-575. 
Albayrak S. and Needet Camas, 2005. Effects of different levels and application times of humic acid on root and leaf yield and yield components of forage turnip (Brassica rapa L.). Journal of Agronomy 4(2):130-133, 2005.

Albayrak, S., N. Camao and C.S. Sevimay, 2004. The influence of row spacing on root and leaf yields and yield components of forage turnip (Brassica rapa L.). Turk. J. Field Crops, 9: 72-77.

Albregts EE, Howard CM, Chandler C (1988). Effect of biostimulants on fruiting of strawberry. Proc. Florida State Hort. Soc. 101:370-372.

Anonymous. 2007 Agresco report of department of Soil Science and Agricultural Chemistry, Nagpur.

Arancon, N.Q., Edwards, C.A., Lee, S. and Byrne, R. 2006. Effects of humic acids from vermicomposts on plant growth. European Journal of Soil Biology, 42: 65-69.

Asenjo, M. C., Gonzalez, J. L. and Maldonado, J. M. 2000. Influence of humic extracts on germination and growth of ryegrass. Communications in Soil Science and Plant Analysis, 31: 101-114.

Canellas, L.P., Olivares, F.L., Okorokova, A.L. and Facanha, A.R. 2000. Humic acids isolated from earthworm compost enhance root elongation, lateral root emergence, and plasma $\mathrm{H}+$ ATPase activity in maize roots. Plant Physiology, 130: 1951-1957.

Celik H., Ali VahapKatkat, Baris Bulent Asık\& Murat Ali Turan,2010. Effect of Foliar-Applied Humic Acid to Dry Weight and Mineral Nutrient Uptake of Maize under Calcareous Soil Conditions. Communications in Soil Science and Plant Analysis, 42:29-38, 2011. Copyright (C) Taylor \& Francis Group, LLC ISSN: 0010-3624 print / $1532-2416$ online.

DOI:
10.1080/00103624.2011.528490.

Chen, Y. and Aviad, T. 1990. "Effect of humic substances on plant growth". In Humic substances in soil and crop sciences, Edited by: MacCarthy, P. 161-186. Madison, Wisc: ASA and SSSA.

Çimrin, K. M. and Yılmaz, I. 2005. Humic acid applications to lettuce do not improve yield but do improve phosphorus availability. Acta Agriculturae Scandinavica Section B: Soil and Plant, 55: 58-63.

David, P. P., Nelson, P. V. and Sanders, D. C. 1994. A humic acid improves growth of tomato seedling in solution culture. Journal of Plant Nutrition, 17(1): 173184.

Delfine, S., Tognetti, R., Desiderio, E. and Alvino, A. 2005. Effect of foliar application of $\mathrm{N}$ and humic acids on growth and yield of durum wheat. Agronomy in Sustainable Development, 25: 183-191.

Dogan, E., \& Demir, K. 2004. Determination of yield and fruit characteristics of tomato crop grown in humic acidsadded aggregate culture in greenhouse conditions. VI. National Vegetable Symposium 21-24 September, Canakkale, Turkey. Pp. 218 - 224.

Dursun, A., Guvenc, I. and Turan, M. 2002. Effects of different levels of humic acid on seedling growth and macro and micronutrient contents of tomato and eggplant. Acta Agrobotanica, 56: 8188.

Ertan Yildirim, 2007. Foliar and soil fertilization of humic acid affect productivity and quality of tomato. Acta Agriculturae Scandinavica Section BSoil and Plant Science, 2007; 57: 182186.

Hameed A., ShabihFatma, Javed Iqbal Wattoo, Muhammad Yaseen, and Saeed Ahmad, 2018. Accumulative effects of 
humic acid and multinutrient foliar fertilizers on the vegetative and reproductive attributes of citrus (Citrus reticulata cv. kinnow mandarin). JOURNAL OF PLANT NUTRITION https://doi.org/10.1080/01904167.2018. 1510506.

Haripriya, K. and P. Poonkodi, 2005. Role of organic mulches and foliar nutrition on changes, nutrient uptake and residual soil fertility in tuberose. Adv. Plant Sci. 18 (1): $175-178$.

Hiradeve P.N., R. D. Deotale, Mita li S. Deogirkar and Swati B. Gaikwad, 2011. Effectivity of foliar sprays of vermicompost wash on chemical, biochemical, yield and yield contributing parameters of groundnut (Arachis hypogeae L). J. Soils and Crops 21(2) 266-272, Dec., 2011 ISSN 0971-2836

Kapase P.V., R. D. Deotale, P. P. Sawant, A.N.Sahane and A.D. Banginwar, 2014. Effect of foliar sprays of humic acid through vermicompost wash and NAA on morpho-physiological parameters, yield and yield contributing parameters of chickpea. J. Soils and Crops 24 (1) 107-114, June, 2014 ISSN 0971-2836

Karakurt Y., HusnuUnlu, HalimeUnlu, HuseyinPadem, 2009. The influence of foliar and soil fertilization of humic acid on yield and quality of pepper. ActaAgriculturaeScandinavica, Section B - Plant Soil Science.

Lende S.R., R.D. Deotale, P.S. Kamble, Priyanka P. Ghadge, and S.M. Suryapujary, 2007. Influence of foliar spray of vermiwash and cowdung wash on biochemical and yield contributing parameters and yield of soybean. J. Soils and Crops 17(2)398-402, Dec. 2007.

Mackowiak, C.L., Grossl, P.R. and Bugbee, B.G. 2001. Beneficial effects of humic acid on micronutrient availability to wheat. Soil Science Society of America Journal, 65: 1744-1750.

Nikbakht A., Mohsen Kafi, MesbahBabalar, Yi Ping Xia, Ancheng Luo, and Nematallah Etemadi, 2008. Effect of Humic Acid on Plant Growth, Nutrient Uptake, and Postharvest Life of Gerbera. Journal of Plant Nutrition, 31: 2155-2167, 2008. Copyright (C) Taylor \& Francis Group, LLC. ISSN: 01904167 print / 1532-4087 online. DOI: 10.1080/01904160802462819.

Padem, H., Ocal, A. and Alan, R. 1997. Effect of humic acid added foliar fertilizer on seedling quality and nutrient content of eggplant and pepper. ISHS Symposium on Greenhouse Management for Better Yields and Quality in Mild Winter Climates, 3-5 November 1997. Acta Horticulturae, 491: 241-246.

Piccolo, A. 2012. The nature of soil organic matter and innovative soil managements to fight global changes and maintain agricultural productivity. In Carbon sequestration in agricultural soils, 1-19. Berlin, Heidelberg: Springer.

Piccolo, A., S. Nardi and G. Concheri, 1992. Structural characteristics of humic substances as related to nitrate uptake and growth regulation in plant systems. Soil Biol. Biochem., 24: 373-380.

Rao, S.C. and F.P. Horn, 1986. Planting season and harvest date effects on dry matter production and nutritional value for Brassica sp. in the southern great plain. Agron. J., 78: 327-333.

Senn, T.L., 1991. Humates in Agriculture. Acres, USA.

Serenella, N., Pizzeghelloa, D., Muscolob, A. and Vianello, A. 2002. Physiological effects of humic substances on higher plants. Soil Biology \& Biochemistry, 34: 1527-1536.

Sharif, M., R. A. Khattak, and M. S. Sarir. 2002. Effect of different levels oflignitic coal derived humic acid on growth 
ofmaize plants. Communicationin Soil Science and Plant Analysis 33: $3567-$ 3580.

Shehata, S. A. Gharib, A. A., Mohamed M. El-Mogy, Abdel Gawad, K. F.andEmad A. Shalaby, 2011. Influence of compost, amino and humic acids on the growth, yield and chemical parameters of strawberries. Journal of Medicinal Plants Research Vol. 5(11), pp. 23042308, 4 June, 2011.

Sheren A. Abd El-Hamied, 2018. Improving productivity and quality of mango using humic acid and vermicomposting leachate in North Sinai. Egyptian J. Desert Res., 68, No. 1, 37-59 (2018).

Shweta, A., K. Yadav, Kiran Kumar and
Mamta Sharmd, 2005. Vermiwash a liquid biofertilizer. Uttar Pra.. J. 25 (1): 97-99.

Visser, S. A. 1985. Physiological action of humic substances on microbial cells. Soil Biology and Biochemistry, 17: 457-462.

Xudan, X. 1986. The effect of foliar application of fulvic acid on water use, nutrient uptake, and wheat yield. Australian Journal of Agricultural Research, 37: 343-350.

Yildirim, E. 2007. Foliar and soil fertilization of humic acid affect productivity and quality of tomato. Acta Agriculturae Scandinavica, Section B, Soil and Plant Science, 57: 182-186.

\section{How to cite this article:}

Jatin Hudda, Ankush Godara and Sarvjeet Kukreja. 2020. Effect of Application of Humic Acid and Vermiwash on the Growth, Quality and Yield of Plants: A Review. Int.J.Curr.Microbiol.App.Sci. 9(11): 1277-1284. doi: https://doi.org/10.20546/ijcmas.2020.911.149 